\title{
Safety Mechanisms for the Autonomy and Independence of the Judiciary
}

- Insights from the third power in Europe in Discussion between the CCJEWorking-Group and the German Commission 'Judicial System' in Berlin (June $23^{\text {rd } 2014)-}$

\section{Introduction}

\section{A. Autonomy and Legitimation}

\section{Country-specific summaries}

1. Most effective topos: logical consequence of separation of powers is autonomy

2. Dual control systems for the third power disrupt autonomy

3. Budget right for the third power: consequence of an expression of autonomy

4. Strength of the third power's legitimacy using direct elections

5. Public transparency of judicial election

6. Equality and intensity of participation and self-administration

7. Manageable size of self-administrative units

\section{Comments from the CCJE Debate}

1. Differing ideological and historical links: Legitimation via election vs. Legitimation via selection

2. The third power legitimizes itself more with guarantees of independence in judicial selection than with judges' election by parliament

3. Fears of a loss of legitimacy due to political influence during the election of judges

4. High legitimation for the third power is necessary in order to counter the concern of executive grasp and influence

5. High value placed on parliamentary legitimation in Germany

6. Effects of the strength of legitimation for judicial self-understanding

7. Problems of dual control models: Ministers of justice instead of judges' councils

\section{B. Human Resources}

\section{Country-specific summaries}

1. Mechanisms of executive personnel control decrease autonomy

2. Forgoing executive personnel control promotes autonomy 


\section{Comments from the CCJE Debate}

1. Lack of intrinsic motivation for the judges

2. Danger of judges' resignation in the further course of their careers

3. Framework conditions to improve motivation and avoid "black holes"

\section{Efficiency and Quality of Legal Practice}

I. Country-specific summaries

1. Positive influencing factors

2. Negative influencing factors

\section{Comments from the CCJE Debate}

1. Judges' efficiency and their (careful) evaluation as a safety mechanism for autonomy

2. Forgoing self-administration of the third power and the historical reasons for this in Germany

3. Practical strategies to strengthen autonomy

4. Budget authority for the third power

\section{Judiciary's Relations with the Public and Media}

I. Country-specific summaries

1. Protection of autonomy with self-administrative organs

2. Country-specific approaches

\section{Comments from the CCJE Debate}

1. Independent judges' councils shape and improve the judiciary's communication abilities

2. The creation of judicial transparency is the task of independent judges' councils

3. Creation of regulations for public communication is the task of judges' councils

\section{E. Independent State Prosecutor's Offices}

I. Country-specific summaries

1. The European principle of separation of state prosecutor's office from the courts

2. European trend: independent criminal prosecution

\section{Comments from the CCJE Debate}




\section{F. Conclusion}

Ten Safety Mechanisms for the Autonomy of the Third Power in Europe

\section{Introduction}

Insights into the realities of four European judicial systems, which the judges and the judicial representatives from the Netherlands, Italy, Poland, and Switzerland made possible for the German Federal-Länder Commission in a collegial manner, show numerous mechanisms through which the third power could and must be supported and secured throughout Europe. Only with strong and effective judicial control can the principle of the separation of powers set limits to the increasing entanglement of powers in the modern party democracy. Only independent control by an autonomous third power can offer effective protection of freedom from public and private abuse of power.

The following five summaries from the "Country-specific minutes" (Experiences of Autonomy of the Third Power in Europe, KritV 4/2014, Part C), which were not created by the Commission Judicial System but by the author, were presented to the participants in the discussion on 23 June 2014 in sections as information. All participants were requested to comment on the presented insights from their personal perspective. Insofar as German was spoke, the debate was consecutively interpreted for the CCJE group both in English and in French. The participants' comments following the five sections were also selected and put together by the author according to subject.

\section{- Members of the Working group of the CCJE}

Lord Justice Sir Richard Aikens, Judge at the Court of Appeal of England and Wales, Vice-President of the CCJE, United Kingdom; Nina Betetto, Judge and VicePresident of the Supreme Court of Slovenia; Nils A. Engstad, Judge at Hålogaland Court of Appeal, Tromso, Norway; Prof. Dr. Stephan Gass, Judge and Vice-President of the Criminal Department of the Court in the Canton Basel-Landschaft, Switzerland; Katarzyna Gonera, Judge of the Supreme Court, Member of the National Council of the Judiciary of Poland; Bart van Lierop, Senior Justice of the Administrative High Court for Trade and Industry in The Hague, The Netherlands, Chairmen of the CCJE; Aida-Rodica Popa, Judge at the High Court of Cassation and Justice in Bucharest, Romania; Dr. Gerhard Reissner, President of the District Court of Floridsdorf, President of the Austrian Association of Judges, Austria; Johannes Riedel, President of the Higher Regional Court in Cologne, Germany; José Fransisco Cobo Sàenz, Magistrat and President of the 2nd Section at the Audiencia Provincial in Navarra, Spain; Duro Sessa, Justice of the Supreme Court, Croatia; Artashes Melikyan, Secretary of the CCJE.

\section{- Members of the German Committee "Judicial System"}

Federal Ministry of Justice: Marie Luise Graf-Schlicker, Head of a Ministry Department at the Federal Ministry of Justice and Consumer Protection; Matthias Korte, Head of Section at the Federal Ministry of Justice and Consumer Protection; Sabine Hilgendorf-Schmidt, Head of Division at the Federal Ministry of Justice and Consumer Protection; Martin Engers, Senior Civil Servant, Federal Ministry of Justice and Consumer Protection; Wiebke Hildebrandt, Judge, Federal Ministry of 
Justice and Consumer Protection; Judith Buttenmüller, Federal Ministry of Justice and Consumer Protection;

Ministry of Justice Brandenburg: Sabine Stachwitz, former State Secretary of Justice, Brandenburg; Dr. Georg Kirschniok-Schmidt, Head of Division at the Ministry of Justice in Brandenburg; Dietlind Biesterfeld, Judge at the Regional Court, Berlin;

Ministry of Justice Hesse: Karl Greven, Head of Section at the Ministry of Justice, Hesse; Katrin Thaler, State Prosecutor/Ministry of Justice, Hesse;

Ministry of Justice Rhineland-Palatinate: Dr. Jörg Schumacher, Judge at the Higher Administrative Court/Ministry of Justice, Rhineland-Palatinate;

German Judges' Associations: Hans-Ernst Böttcher, Former President of the Regional Court Lübeck, Representative of the Judges' Association "Richterinnen und Richter in ver.di"; Elisabeth Kreth, Judge at the Finance Court Hamburg, Representative of the Judges' Associaton "Deutscher Richterbund"; Heinz Stötzel, former Presiding Judge at the Finance Court, Representative of the Judges' Association "Neue Richtervereinigung";

Scientific Moderation: Prof. Dr. Peter-Alexis Albrecht, Institute of Criminal Sciences and Legal Philosophy, Law Department, Goethe-University of Frankfurt, and Mareike Jeschke, Scientific Secretary.

\section{A. Safety Mechanisms in the Area "Autonomy and Legitimation"}

\section{Country-specific summaries}

\section{Most effective topos: logical consequence of separation of powers is autonomy}

The strongest impulse for the autonomy of the third power is rooted in the democratic basis of the separation of powers. This is legitimized by the direct election of all judges by the carriers of the three state powers: the people. Theoretical and/or normative goals upon which their independent structures are created are secondary to the strength of legitimacy by direct elections. This is seen not only in the assessments of the Swiss judges, but also in those of the judges from the Netherlands, Italy, and Poland:

\section{Autonomy as a "business model" (Netherlands)}

The primary focus on business goal concepts in the Netherlands (autonomy as a business model) shows: despite the courts' personnel selection competencies, there is discontentment among the judges about the lack of opportunities for participation in the Judicial Council and in the self-administration processes. This leads to a lack of support by the majority of the judges. The Dutch judges demand possibilities of direct influence as well as representation of all instances in the Highest Judges' Council. In addition, the lack of autonomy has led to a bureaucratization of jurisprudence.

\section{Goal: "historical legacy" (Italy)}

The historically legitimized autonomy concept of the Italian judiciary ("the antiquated historical ideal") also leaves the judges hardly any practical space for self-administration. Hierarchies were deconstructed and a separation of career and salary was normed, 
and while this supported autonomous judicial awareness, these autonomy structures were counteracted by extensive disciplinary regulations for the judges, by strict and constant evaluations, and by the judicial councils' limited authority in personnel matters on all levels.

\section{Model change of system: "the revolution devours its children" (Poland)}

In Poland, there is only a very low level of awareness of judicial primary legitimation. The revolutionary emancipation draft from 1989 has yielded to consuming processes of executive influence. Hierarchical salary structures, control by court presidents and most recently autonomously acting administrative directors responsible directly to the ministry, and a strict and constant system of evaluation of judicial activity seriously reduce impulses for self-administration.

\section{Dual guidance systems for the third power disrupt autonomy}

The comparison of Switzerland with Italy and Poland makes it clear that dual systems of responsibility for the third power are counterproductive. In Italy and in Poland, in addition to the judicial councils, the executive in the form of the ministries of justice are given massive competencies for interference in the autonomy of the third power. This tension is always dependent on the particular political situation in Italy - as described by the judges -, and in Poland on the current perspective of the political class which is showing a more restrictive view of the development of judicial autonomy and selfadministration in the interest of increasing the executive branch's influence. In the business-oriented Dutch model, the problem is not with a dual structure of responsibility, but with the fact that the Judges' Council was legally given sole executive competency which essentially replaces the role of the ministry of justice in Italy and Poland without sufficiently including the judges.

\section{Budget right for the third power: consequence of an expression of autonomy}

An autonomous right to submit a budget correlates directly with the strength of legitimacy for the independence of the third power. The Swiss judiciary - depending on the canton also at the level of the instances - directly negotiates the judicial budget with the parliaments. Inexperience in the area of state budget can first be balanced by the appointment of external expert consultants. The dependence on financial funding by executive instances and the possibility of influence by restrictions on how the funds are to be used could counteract independence guarantees on other levels. That is the case in Italy and Poland. In the Netherlands, the macro-structural distribution is done directly by the Judicial Council, and the courts then have competency in distributing those funds. Only the four-member Judicial Council negotiates with the Dutch budget organs.

\section{Strengths of legitimizing the third power using direct elections}

The most important safety mechanism of the third power is the strength of its judges' legitimacy. The stronger the legitimacy of the judges' appointments by direct popular 
election or by direct parliamentary election, the stronger the experienced and lived autonomy - something particularly apparent in Switzerland. The opposite can be seen in recruiting procedures done by judges' councils or their committees for indirect appointment of judges in Italy and Poland. The judicial self-co-optation in the Netherlands - despite impressive transparency of the criteria - is at the bottom of the list of countries reviewed in terms of strength of legitimacy. Despite all possible criticism of the system of direct election of judges if the time in office is limited (self-censorship), the example of Switzerland shows in an impressive manner: direct democratic legitimation of the third power is linked to the result that it works with the other state powers on an equal playing field, that is, it is an equal and independent state power.

\section{Public transparency of judicial election}

The transparent link of Swiss judicial elections with political party affiliation may seem strange at first glance, but the election of judges to the German Federal Constitutional Court shows that party affiliation does not have to be a hindrance for autonomous jurisprudence. The public political confession, at least in Switzerland, is preferred in contrast to indirect or concealed political selection by executive organs or other interest groups, such as co-optation by other judges. An election of judges for an office which is given for life or at least for a long period of time should probably be given preference over a short time in office with re-election, as can be seen in the most recent reform steps in Switzerland, as well. In direct elections, this strengthens the external and internal legitimacy of the judges.

\section{Equality and intensity of participation and self-administration}

It is important that all instances have an equal amount of autonomy. Supervision by a higher instance can seriously disturb the autonomy and its positive effects - which can be seen in the example of Switzerland. Directly linked to the strength of legitimacy is the judges' participation on all structural levels of judicial self-administration. Through this, the judges' participation in self-administration becomes a precondition for an effective, autonomous judiciary.

\section{Manageable size of self-administrative units}

Important support of working structures and autonomous motivation results from the size of the self-administrative units: the smaller they are, the more the judges can be included and the stronger the understanding of self-responsibility for the functioning of jurisprudence is influenced. Only through this do judges experience the realization of judicial administrative tasks as "their own concern." It is seen as ensuring that the judges remain "down to earth" and is more effective in terms of evaluation of actions due to the proximity of the judges to the issues at stake. Federal states make it possible to keep self-administrative units small. The larger the self-administrative units are, the more authority must be given to the self-administrative organs, which could cause new power 
conflicts between judges and the self-administrative organ. Insofar as judges do not act from the plenum but through organs of self-administration, these organs need the support and feedback from the majority of the judges.

\section{Comments from the CCJE Debate*}

In this part of the debate with the CCJE, the primary focus was on questions of the third power's legitimation (direct election, parliamentary election, independent judges' selection committee) and the effects or "non-effects" deriving from this main point. The topos "Legitimation of the Third Power" was discussed from the perspective of the CCJE speakers not so much in regards to election but rather in regards to selection. Not until the second discussion section (personnel management) were questions of judges' inner motivations and the encouragement/stabilization of these discussed, and not until the third section did the participants concentrate on essential considerations of systemic changes - in particular the independent budgetary rights of an autonomous third power.

\section{Differing ideological and historical links: Legitimation via election vs. Legitimation via selection}

- The Dutch judge noted that the election procedures for judges depend on the specific ideological and historical conditions of each country. Legitimation has nothing to do with the election or selection of judges, but arises solely by belonging to the third power. A connection to the political level (parliament and executive) may and must not be made. There are models that place (direct) election at the forefront. One has to realize, though, that this model or this system is not necessary or self-explanatory but means a political or ideological decision has been made. You can decide to do it, but that should not be equated with believing it is the best or only decision (van Lierop).

- The German representative of the ver.di judges affirmed this ideological and historical dependency. The idea of a strong legitimation of the third power arose in Germany as well as in Italy from the examination of the fascist past. It came out of the impression that even in the Weimar Republic the judges thought in an authoritarian manner and oriented their activities on the executive. In the time of the NationalSocialists, numerous members of the judiciary felt that they were willing participants of the ruling political class. That is why, after 1945, the democrats showed in a large coalition with all parties that they no longer wanted judges to be appointed by the executive. The intention was to create plurality in the judiciary with the plurality of the parliaments in order to strengthen the idea of being bound to the laws, which are passed by parliament. Perhaps there was a typically German idea underlying this that

* I would like to thank Kelly Neudorfer for her competent translation of the minutes of the debate with the Council of Europe's working group (CCJE). I would also like to thank Mareike Jeschke, my academic assistant, for taking the minutes, (re-)translating, and summarizing the results of the discussion. The original version of the minutes is available as an annex to her dissertation, Judicial Autonomy in Europe, Frankfurt, 2015. 
every state power needs to be derived from the parliament and the members of the judiciary would have a higher degree of legitimation if they were elected by the parliament instead of being appointed by the executive, which is also only indirectly legitimized (Böttcher).

- The Austrian representative added that for him, as well, the third power derives its legitimation from the fact that it is an independent and impartial institution. Regardless of which system of appointment one chooses, a safety mechanism must be included that is oriented on international standards and ensures that the appointment process does not conflict with the judges' independence. One of these standards is to focus on the suitability of the candidates in the selection process. This is easier said than done, however. How you can guarantee it in the practice is a challenge that must be faced (Reissner).

- From the Slovenian perspective, the more systems are analyzed, the clearer it becomes that there can be no set rules for how judges should be appointed in an autonomous judicial system but instead the national particularities are and must be taken into consideration. Each system design must do justice to the unique historical conditions. That is why you can't agree with the generalized statement that legitimacy is directly correlated with parliamentary appointment. In some countries this works, in others it doesn't. The same applies to the political membership in a party. This may work in Switzerland, but it wouldn't be possible in an Eastern European country with a communist past, for example. There the judges may have been formally independent under the regimes, but they always acted in the name of the party. A re-introduction of this "tradition" could not be justified there. There are a few abstract rules upon which judicial appointments should be oriented, but each country must make adaptations itself and choose the system best suited to its needs and circumstances (Betetto).

2. The third power legitimizes itself more with guarantees of independence in judicial selection than with judges' election by parliament

- From the Norwegian perspective it was added that the principle of the separation of power is key for a democratic state and must be secured by the constitution. It is also an essential foundation for the legitimation of the judiciary as an independent state power. But there are other aspects than only asking who elects or selects the judges. The parliamentary appointment of judges does not contradict the principle of the separation of power, but it is also not a necessary conclusion from it. The consequences of this decision need to be carefully considered. And if instead or in addition there is an independent selection committee that evaluates the judges' abilities before their appointment, then one should also consider the legitimation of the committee. The design of such a committee could also vary among countries and reflect the historical particularities, and this must be accepted. From the Norwegian perspective, for example, it would be important that the organ reflects the largest portion of society as possible. This may not apply equally for every European country, however. In all 
of this, certain basic conditions must be upheld. If one speaks of legitimation, then one must also include public trust in the judiciary. This also means that the independence of the judiciary and the courts are made visible to the public. One possibility to symbolize the understanding of judicial autonomy to the public would be the transfer of administrative tasks to the courts. In Norway, the administrative tasks were transferred from the Ministry of the Judiciary to an independent court administration agency 12 years ago. This was a big step to improving the picture of an independent judiciary. Although it seems to work from the outside, internally it can also be viewed critically. The Norwegian judges feared that large elements of power remained with the executive. Another area in which Norway was able to make judicial independence visible was the independent appointment committee. It was important to transfer this authority from the Ministry of Justice to an independent organ. Finally, transparency is also key. You need to make the selection and appointment procedure for judges transparent, say who applied and which candidate was chosen for which reasons. It is no less important to make transparent how a court works. Society must be able to obtain insights into a court's procedures so that the court can show its responsibility for its tasks (Engstad).

- For the Slovenian judge, it is very important that if the path of parliamentary election is chosen, there is an organ which conducts the first selection process and checks the suitability and capabilities of the judicial candidates. If the parliament then only confirms a candidate or chooses from a pre-filtered list of two or three candidates whose qualifications have been verified, then the system could work because the balance of powers is thereby preserved (Betetto).

- From the Romanian viewpoint, it is also essential from the CCJE perspective that the judges' independence is guaranteed by a careful selection. Orientation on suitability is important, but it is just as important that judges are offered continuing education after their appointment and thereby enabled to professionally exercise their position. In Romania there have been positive experiences with having the judges of the constitutional court elected by the parliament even if the final, formal act of appointment is carried out by the president. These judges' work is independent even though they are elected. What is necessary is a balance among the state powers. The election is then on the one hand a political process, but on the other hand it leads to political responsibility being taken on (Popa).

\section{Fears of a loss of legitimacy due to political influence during the election of judges}

- The Norwegian representative even expressed surprise about the significance given to "parliamentary elections" revealed in the country surveys. Internationally - also from the perspective of lawyers - concern is shown that if the judicial candidates are appointed or elected by the parliament, this could lead to a politicization of the judiciary. The UN Human Rights Committee had already recommended in its General Comment No. 32 that judges should not be appointed to office by the parliament based 
on the fear that the judiciary would thereby be politicized. International recommendations therefore tend more towards suggesting that judges are appointed based on their suitability. Their abilities, skills, and competencies should be the focus. It is also recommended that the evaluation of these abilities is done by an independent organ. In Norway, this kind of independent commission recommends three candidates to the Ministry of Justice based solely on their suitability, and one of them is appointed. This appointment and selection is no longer a political decision and has nothing to do with party affiliation or political leanings of the applicants. If this system were to be changed in Norway to a selection system in which the parliament participated, from his viewpoint the judiciary would lose legitimacy because the candidates would be seen as politically appointed judges. The strength of their system is that the judiciary is not political or viewed as being political. That is why trust in the judiciary is very high in Norway in contrast to trust in politicians. If the politicians were allowed to appoint judges, this trust would decrease dramatically. The introduction of the election of judges would therefore have the opposite effect than that which is intended (Engstad).

- The discussion partner from Great Britain noted that from the British perspective, Germany seems to have a democratic and balanced constitution and the judiciary is perceived as being independent. In England the judges are even often accused of acting independently if they make decisions which go against the so-called will of the people, which is expressed in the laws and decisions of Parliament - or at least these laws and decisions claim to have understood the will of the people. From his perspective, the selection of judges should be about developing a system that guarantees the besteducated people will be found and chosen in a procedure that is free from political influence. It is difficult to develop this kind of system. In Great Britain, the process of judicial appointment was changed only five years ago. However, only very few judges have the impression that anything has changed in terms of the quality of those selected or their legitimation. You need to be careful with the idea that judges have a higher degree of legitimacy if they are elected by the people or parliament. From outside this could lead to the impression that the judges are affiliated more with one party than is the case if they are appointed by the executive. He therefore asks whether in regard to this aspect, Germany is too sensitive since at least from outside it seems that everything is just fine. Great Britain sees one serious difference to the German selection of judges in the following: There, all judges have already had a professional career. They were attorneys who were also independent and not anyone's employee. They were raised with the idea of acting independently of state interests (Sir Aikens).

\section{High degree of legitimation for the third power is necessary in order to counter the concern of executive grasp and influence}

- The motivation for the high degree of legitimacy of the third power is continually emphasized with the requirement of its independence. From the Austrian perspective, the question of why one wants to structurally improve the organization of the judiciary can be answered by seeing that the current system is subject to opportunities for influence. For example, the financial crisis showed that financial institutions which 
used the executive as an agent tried to indirectly influence the judiciary's handling of the crisis. Systems should therefore be made resistant for future developments, even if there might not currently be a need (Reissner).

\section{High value placed on parliamentary legitimation in Germany}

- The representative of the German Judges Association (DRB) does not believe that judges must necessarily be elected by parliament, but the more direct the democratic legitimation, the greater the self-understanding that they are part of an independent power. It would therefore be important to look into a middle path in which there is a strong democratic legitimation of judges on the one hand, but which on the other hand prevents politicization in the selection process and guarantees appointments based on suitability, performance, and skills - as required by the Basic Law. For her, this middle path is the institution of a judicial selection committee with the participation of parliament, the judges, and possibly attorneys. That a judge carries out his tasks with more legitimation and a greater self-understanding due to an election is something she finds important. Particularly with the German background, in which there seems to be a bureaucratization of the colleagues, that is, a change of attitudes toward a more civil-servant understanding of the tasks, she would find it helpful if their self-confidence were strengthened by more legitimation (Kreth).

- The position of the judges' representative from ver.di is also similar. Each country needs to find its own way on the basis of a few common principles. History also plays a role in this. The individual Länder are free to determine the appointment process for the judges at the Länder level. But the comprehensive implementation of the separation of powers was stopped halfway, and some Länder maintained appointment by the executive. The fiercest opponents of strengthening the judicial selection committees, e.g. by a high degree of parliamentary participation, are therefore those who would rather have the executive remain strong. But that is not shown openly. With Germany's history, those who speak out against parliamentary participation usually have the ulterior motive of thereby maintaining the influence of the executive. Autonomy as a whole is hardly helped by this, however. As a guiding principle one could say that there is not just one perfect path for everyone, but based on a few principles the Länder must be allowed to work out the details of the appointment procedures. In $1997 / 98$, the writing of the European Charter was dealt with as a judicial statute. There it is set down that the appointment of judges is to be done by an independent committee and according to the criteria of professionalism. This was not intended to exclude the development of judicial elections by the people or parliament, however (Böttcher).

\section{Effects of the strength of legitimation for judicial self-understanding}

- Importance was placed not only on aspects of legitimizing the third power. The positive and negative effects of the strengths or weaknesses of legitimation were also discussed. From the New Judges Association (NRV), the comment was made that 
particularly in Switzerland the tradition of self-administration in the courts is just as old and secured as the democratic constitution itself. There, the self-administration in every instance is carried out as an outflow of the separation of powers. This has the consequence that those who are selected are obligated to take on the self-administration tasks and to assert these vis-à-vis all political influences regardless of the level from which they come. This affirms the now undisputed insights from organizational sociology which say that decisions are best made where they occur, and that the direct responsibility for an activity should be realized in the lowest instance. This means that the judges are given the responsibility of taking care of everything that has to do with self-administration. By doing so, it signals to the outside world that they are confronting someone who was elected by the parliament or the people and carries out his charge in fulfilment of the constitutionally anchored idea of self-administration (Stötzel).

- According to the Austrian judge, the self-understanding of judges can be linked directly to their working environment. As already described in the case of Germany, he perceives that more and more judges see themselves as civil servants in other countries like France or Austria, as well. But if you have to ask for every resource, if you can't influence your working environment, then from outside you will also look increasingly like a normal civil servant (Reissner).

- The Dutch judge stated that the judges' self-understanding is a key aspect of independence. In Germany many judges are frustrated - as noted by the German judges in the working group - and there is a lack of appreciation. On the inside, not everything is as it appears from the outside. From his perspective, the experience of self-administration could improve this feeling. The aspect of a judges' self-perception is not just a romantic idea but it is important in a late-capitalist society that has to re-think the role of the priority and reservation of the law (van Lierop).

\section{Problems of dual control models: Ministers of justice instead of judges' councils}

Only a few contributions in the first part of the debate focused on the question of dual structures of the (self-)administration of the third power.

- The former president of the CCJE working group noted that it is counterproductive to set up a dual system (that is, the ministry on the one hand and a judges' council on the other) with control tasks. The experiences from Poland, Italy, and the Netherlands clearly showed the questionable nature of that kind of external control by the executive. From the perspective of this judge, everything else is based on this essential decision - as the example of Switzerland shows: there, there is no external executive control by ministries of the judiciary (Reissner).

- Following this perspective, that would imply not as much the question of the legitimation of the third power but the legitimation of the executive judicial administration 
as a whole, which would need to be discussed critically (Kirschniok-Schmidt, Brandenburg Ministry of Justice).

\section{B. Safety Measures in the Area "Human Resources"}

\section{Country-specific summaries}

Particularly the area of human resources correlates strongly with the degree of the judges' legitimation. The more independent the judges are, the fewer extrinsic control mechanisms can be seen.

\section{Mechanisms of executive personnel control decrease autonomy}

Systems with a strong dependency on the executive such as Poland, but also Italy, show the following characteristics due to a limited authority in matters of personnel:

- A complete system of professional evaluations which rely heavily on formal criteria such as workload quotas,

- strict use of disciplinary investigations,

- dependency on the instructions of the court presidents,

- a dual subsystem of administrative guidance and presidential influence,

- executive responsibility for judges' education.

These kinds of judicial systems are characterized by a strong executive profile even if, such as the case of Italy, hierarchical structures are to be counteracted by the dismantling of salary differences in careers. The quality of salary in all instances should promote intrinsic independence. But this alone is not enough for the creation of strong independence, as can be seen by the assessments of the Italian judges.

\section{Forgoing executive personnel control promotes autonomy}

The Swiss judicial system mostly does without controlling judges using organizational guidelines. Even if, as was reported, the internal judicial promotion is primarily dependent on party affiliation, the lack of external personnel policies has extremely positive effects which can be seen in the self-assessments:

- Besides the party quota, the legal qualifications are important for filling positions. Other factors are not named.

- The Swiss are critical of the election of judges for a limited time (self-censorship), but it is rare a judge is not re-elected.

- Salary models are set by the parliaments (whether they are equal or differ depends on the canton).

- Disciplinary regulations are almost obsolete when the election is for a limited time.

- Formal methods of evaluation essentially do not exist.

- Court presidents are elected speakers for period of time (without being supervisors). 
- Only in some cantons are there power problems between lower and higher instances if the parliament has given the instances different competencies.

- External influences in personnel policies cannot be seen.

- In all questions, the judiciary is on a level playing field with the parliaments.

The judges' contentment with a lack of executive control is also heard from the Netherlands. There the judges cannot participate in the macro-structural decisions of the fourmember Judges' Council, a fact which is harshly criticized. Due to the authority in personnel matters, which to a great extent lies with the individual courts, there has been a dismantling of judicial hierarchies due to the following factors:

- an alignment of salaries,

- reduced evaluation processes, and

- a country-wide restrictively used disciplinary system.

That encourages confidence in their autonomy that is seen in the powerful opposition of the Dutch judges directed in writing and in professional organizations against their lack of participation in the macro-structures (cf. Nederlands Juristenblad 2012, p. $2616 \mathrm{ff})$.

\section{Comments from the CCJE Debate}

\section{Lack of intrinsic motivation for the judges}

Especially among the discussants from the represented judges associations, but in agreement with all others, it was determined that there was a lack of professional motivation in judges. The participants oriented their statements less on the results of the country comparisons and more on their own experiences in their profession and the associations.

- The representative of the German Judges Association asked herself to what extent one could do without those kinds of personnel control systems - like evaluations and promotions - and still maintain a very efficient and high-performing judiciary as it exists in Germany. That is a question that needs to be asked. Within the judiciary there are very few intrinsic incentives to perform, and therefore many believe that extrinsic incentives - that is, a promotions system based on evaluations - are still necessary in order to guarantee that the best are chosen. Intrinsic incentives are work satisfaction and the job itself. It is questionable, though, whether these can serve as a sufficient basis for a long-term willingness to perform at a high level. In this context, she can say that right now the judges' satisfaction with their work is greatly decreasing. This has to do with the feeling of a lack of appreciation, which is currently primarily based on insufficient salaries (Kreth).

- For the representative of the judges in ver.di there is a great deal of intrinsic motivation which is the reason many became judges in the first place: Both on the micro-level of the individual case but also in structuring the judiciary to ensure what is commonly called justice. But nothing is more logical than to say that they want to do on a small 
scale what is called justice on a larger scale. This is a good intrinsic motivation for judges. He believes that is better if the judges take care of their own organization and administration since each individual then has the feeling that he is participating and not only an object of the administration - like a civil servant. This gives the feeling of being an independent judge, you can decide autonomously and be sure of having the colleagues' support if you're criticized for such decisions. This kind of intrinsic motivation becomes so natural that it should also be expressed externally (Böttcher).

- The representative of the New Judges Association (NRV) made it more concrete: if you have working conditions that take up your energy in all areas, that give you responsibility also for the environment within which adjudication takes place by allowing you to co-determine processes, select staff, and include them, then this will lead to a different kind of intrinsic motivation. That is better than if you are assigned certain tasks and can't contribute to anything that determines the environment of judicial activities. This was heard persuasively from the Swiss judges when they described how the eleven judges of a court met voluntarily twice a week and actively participated in order to discuss and coordinate questions of the court's organization. Too many of his German colleagues - especially those in the first instance - have become apathetic because they have the feeling it doesn't make any sense to participate (Stötzel).

- The Austrian association representative also feels that intrinsic motivation is key. The selection process must be able to guarantee that this prerequisite is met. If you think you need promotions and need to use an evaluation system for this, then you should ask whether everyone should be subject to this evaluation system (that is, even those who are not interested in a promotion), and whether that doesn't produce the opposite effect as that which is desired in the long-term: That instead of achieving recognition and motivation with promotions, pressure and frustration are created that hinder the judges' work. Finally, for him, it is essential that conditions are created such that the judges are placed in the area best for them and that they are provided with the continuing education necessary for that area (Reissner).

\section{Danger of judges' resignation in the further course of their careers}

- The German CCJE representation is responsible for 850 judges in his higher regional court district. Especially the newly appointed judges have excellent subject-area qualifications and also have the necessary "soft skills." Without exception, he comes out of these discussions with the conviction that the young judges are well-balanced people who take their work seriously and with responsibility and who strive to find a balance between precision and speed in processing cases. From his personal experience, he is therefore not worried about the intrinsic motivation of the career entrants. What worries him, though, is how to find a way to prevent this initial enthusiasm from turning into resignation. This is the primary task of those responsible for personnel. Retaining motivation influences everything else. You need to ask how you can make it clear to the judges that motivation is not dependent on promotion and salary, but 
that it results from a satisfaction that is derived from the awareness that they are serving justice and those who seek it (Riedel).

- The Dutch judge agreed with this in principle. It is difficult to retain professional motivation - especially towards the middle or end of the career. This problem also exists in the Netherlands or France. That is why international meetings of judges are necessary in order to find out how to motivate young judges and make them conscious of their task in society. Here you could profit from the experiences of other countries. The Netherlands have had good experiences with ongoing training of subject-area and social competencies. It is important to find candidates who suit the judiciary in terms of their subject expertise and personality, but it is just as important to keep them qualified (van Lierop).

\section{Framework conditions to improve motivation and avoid "black holes"}

- The New Judges Association representative sees Mr. Riedel's contribution as a plea for self-administration. You should ask how you can maintain the motivation of young judges after they are well-educated and enter their careers with a high level of motivation. Self-administration offers the possibility of expanding their opportunities for taking action by forcing the colleagues to act. If they had to evaluate other questions - daily or weekly - other than their purely legal questions, and if they received recognition for this work with feedback either from the administrative area or from colleagues, he could imagine that this would offer additional or different motivation - something that the Swiss colleagues had clearly described. The profile of requirements would then be broader and not limited to purely legal dogmatics. This might enable motivation to be maintained over a longer period of time. A serious problem of a judge's work is that you work into a black hole. If you have other areas in which you work, then you could work toward those. He has always had the experience that judges who are given additional tasks do excellent work in these areas since they develop talents there that they didn't even know they had (Stötzel).

- The Croatian judge also does not see the motivation of young judges as a problem since they are usually highly motivated. But it is more difficult to maintain this high level of motivation. For him, an important factor in this is external recognition, which is seldom given. Instead, media and politicians - the former usually led by the latter - criticize the judiciary for its actions. The colleagues need to support each other in order to not to take such criticism personally. When the heads of the courts are responsible to the ministry, this doesn't work, as they have to follow the direction of the ministry. This would be a vicious cycle. That is why, for him, self-administration and motivation are very closely linked (Sessa).

- From the perspective of the judge from Great Britain, the most important aspect for motivation is that the British judges feel they are independent. They can create their working conditions themselves and feel that their work has its own intrinsic value. 
That does not mean that many judges don't feel overworked, but this feeling can be overcome (Sir Aikens).

- The Norwegian judge commented that the German and Norwegian judiciary systems can hardly be compared. The number of judges at the Cologne district court alone is more than the amount of judges in all of Norway. As in England, in Norway people become judges who already have one or even two careers behind them, either as lawyers in the private sector or in administration. Also as in Great Britain, in Norway it is the last stage of the career. Norwegian judges therefore make a conscious decision to take on this profession and enter with a feeling of pride. That may be one of the most important aspects for maintaining a high level of motivation, that you take pride in your work and are aware that you are carrying out a job that is essential for society. He also links the level of motivation with the level of recognition received from external actors. You're proud if you are respected and valued by others for your work. He identified one de-motivating factor as the high caseload that is often connected to the feeling of not being able to put enough effort into one's work in order to achieve sufficient quality. The unbalanced proportion of caseload, efficiency, and quality is something he sees as a de-motivating aspect. For the Norwegian system, it is also helpful that all judges are generalists. Work is varied since you work on criminal cases as well as civil law and administrative law cases. Each day is different. From his experience, he can say that this is also important for long-lasting motivation. On this point, the Norwegian system is different from most European systems. Of course there are judges who would feel more comfortable if they could specialize. But most are satisfied with this judicial structure. Another factor for motivation that he names is the continual education of the judges. The Norwegian judiciary is trying to improve further in this area (Engstad).

- The Romanian judge reported that the general continual education of the judges has been decentralized and transferred to the appellate courts. This is an attempt to find a balance between continuing education in the National School of Judges and the decentralized units at the courts in order to coordinate the various levels. Coordination among the individual education institutions is also important. In addition, an emphasis is placed on international discussion. For example, there is a partnership with the Norwegian judiciary and meetings for joint continuing education. This look from and at the outside is important to maintain perspective. The exchange not only takes place with judges, but also with professors and practitioners (Popa).

\section{Safety Mechanisms for "Efficiency and Quality" of Legal Practice}

\section{Country-specific summaries}

The efficiency and quality of the judges' work is closely linked to the scope and extent of the autonomous inclusion of judges in the self-organization of the judiciary. This could be clearly seen in the discussions. 


\section{The following positive influencing factors could be seen in Switzerland:}

- The judicial administrative experience is the most efficient system of quality assurance.

- The closer the inclusion of the individual judge in the organization of the courts is, the higher the feeling of responsibility for the functioning of the judiciary.

- The social and personal competencies of judges are seen as particular qualifications which ensure the quality of judicial work.

- No pressure with work statistics can be seen, and therefore there is also no deep quality debate.

- Basis democracy as a model, court administrative leadership in a collegial form, and quality control with cross-court discussions as well as staff meetings and plenary sessions are the Swiss cornerstones for judicial efficiency and quality in their judges' work.

\section{In contrast, the following negative influence factors were named:}

Orientation on statistical criteria which are ordered and evaluated by the executive is not only quality-neutral but is clearly seen as quality-decreasing in the Netherlands, Italy, and Poland if the administrative practice is substantially focused on it.

In Poland, due to executive control, it is commented that the dominance of statistics for everyday judicial practice leads to a distortion of court reality. Because of this, the goal of increasing efficiency is followed ad absurdum, for example by the judges artificially breaking down a procedure in order to create more procedural stages for the statistics. The stronger the executive's interference using evaluations, pay incentives, and discipline, the stronger the judicial criticism. The court president is not primus inter pares but is seen as the extended arm of the Ministry of Justice. Polish judges do not participate in the efficiency and quality structures.

In the Netherlands, the fear of a reduction in quality as a consequence of a lack of opportunities for participation in structuring judicial working conditions is seen. Bureaucratization is the consequence, and the consequence of bureaucratization is a clear decrease in the quality of legal practice.

Italian judges confirmed the negative influences of a lack of participation, but they also point out normative barriers which can only be set aside by the legislature: the primary problem in the Italian criminal justice system is, for example, the extended length of proceedings as a result of legal regulations and the quick statute of limitations despite ongoing proceedings. Added to this is a lack of clarity as to what quantity and quality mean in the search for justice, and it is hardly a surprise that the public has a negative picture of the judiciary. 


\section{Comments from the CCJE Debate}

\section{Judges' efficiency and their (careful) evaluation as a safety mechanism for autonomy}

- A second important aspect for legitimation is efficiency. Society's trust in the judiciary depends on high-quality, efficient work by the courts. Both aspects must be mutually balanced. One experience in Norway was that the transfer of authority from the ministry to the courts led to more efficient processing. The courts brought in professional help for completing the new tasks and worked out an efficient case management system (Engstad).

- All evaluation processes, according to the judge from Great Britain, have the risk of negative effects for the judges' independence. The degree of risk depends on who is given the task of evaluating, that is, whether they are out of the courts' control and carried out by the executive (Sir Aikens).

- The Romanian judge stated that evaluations in Romania are carried out once every three years. A committee made up of court presidents and representatives from the Highest Judges' Council is entrusted with the evaluations. Both judges and state prosecutors are evaluated. Criteria for the assessment include the appeals quota and the number of processed cases. There are efforts to include both qualitative and quantitative aspects. Usually the evaluations are positive. However, the system is also criticized. The Highest Judges' Council is now reacting to the critique and reevaluating the criteria for the evaluation (Popa).

- From the CCJE perspective, the Slovenian judge believes it is important that a balance between evaluation and the judges' independence is kept. Although no conclusive opinion has formed, you could say that a tentative conclusion has been reached that it is necessary to set up safety mechanisms on the procedural level for evaluations. For example it must be guaranteed that the judge can appeal his evaluation and that the evaluation criteria are transparent. In addition, it should be ensured that not only quantitative criteria are used in the evaluation (Betetto).

\section{Forgoing self-administration of the third power and the historical reasons for this} in Germany

- The representative from the Ministry of Justice in Hesse reports that the administrative activities are not viewed as interesting by the judges and are therefore not popular. In the past there were efforts to introduce modern elements of management, especially in relation to the staff other than judges. Those efforts were not received positively rather, they were thankful to be able to point to the judicial administration on questions of personnel management (Greven). 
- The former state secretary from Brandenburg wanted to remark blasphemously that as a young judge she also saw that there was little motivation amongst the judges to take on tasks that didn't have to do directly with jurisprudence. In her opinion, that's not due to a (lack of) commitment on the part of the judges but to the decades-long damage done to the judiciary. This damage was done because it has been and is tradition in Germany for the executive to extend its reach deep into the concerns of the judiciary and regulate things for the judges. Over generations, this has led to the attitude described above. After all, it's not true that the judiciary is content with what is happening in the courts, with their working conditions, the personnel problems, or the building conditions. These issues are criticized daily without being able to show self-initiative for change. As a young judge in Münster, she pled in her own judges council that the meetings of the executive committees in which decisions were reached about the judges' concerns should be open for judges to attend. This suggestions was rejected by a majority. No interest was shown in what was discussed in the meetings. Judges are not all malicious people, but it is the decades-long paternalism that has led to them withdrawing from most - if not all - of the administrative issues. The example may not be representative, but it does reflect her forty years of experience (Stachwitz).

- But there are still more reasons to argue for more self-administration for the judiciary stated the representative of the unionized ver.di judges: On the one hand it's difficult to even be understood anymore in international committees like the CCJE because from the outside one doesn't really have a contact person in Germany, and the Federal Ministry as the representative of the executive first has to play the role of the middleman. Another reason why he thinks Germany's judiciary needs to be constituted differently is that many of the unwritten rules of judicial life come either from the German Empire of Wilhelm II - if not even from Wilhelm I - or from the edict of the Reich Ministry from 1935, such as the unwritten real constitution of the federal German judiciary with the hierarchical structure of the courts (district court - regional court - higher regional court - ministry). This edict, which is partially no longer valid but partially still in effect, and which certainly provides the basis for the practice of judicial administration in Germany, is the root of the principle that the regional court presidents are the supervisors of all judges in his regional court district, and the higher regional court president is the supervisor of all the judges in the higher regional court district. And the minister of justice rules them all. And because at the time this edict was created the Reich minister in Berlin was far away from all court districts, the higher regional court presidents were the unrestricted rulers over the judges in their district. This is no longer true today, and no one would deny their commitment to democracy, but they are still operating in the same structures that were created in 1935. These structures mean in turn that there are only a few who have a say - the Führer principle - and there are many who are only to follow orders. This structure does not fit judges, though. Despite the fact that there are 20,000 decidedly democratic judges, due to the permanent life in this system something from the spirit of yesterday has remained. This is what Ms. Stachwitz described with the power of tradition. Sociologists have already described it: there are norms that are stronger than written law, 
stronger than the constitution. When he describes this, maybe it will be easier for the European colleagues to understand why in Germany the question is asked so urgently why and how the judiciary is organized differently in other countries. At any rate different in that hierarchical ties have been avoided; ties that take away the air to breathe from the individual courts and the individual judges. And they want to breathe (Böttcher).

\section{Practical strategies to strengthen autonomy}

- The Dutch judge asks himself how that can be changed. Really, you would have to initiate a discussion in the judiciary immediately - tomorrow, if possible - at every court and can't allow yourself to be discouraged. He would like to say something from his own experience. A while ago in the Netherlands, an urgent letter from the judges was published that criticized the bureaucratization of the courts. As a result, the highest judges' council reacted and called upon the judiciary to work out a set of professional regulations to bring up for discussion. Now in the judiciary there are consultations about which standards could be set for the just and efficient dispensation of justice. He viewed the shift of the discussion to the judges themselves as a positive development and, at the same time, as a challenge for anyone who wants to deal with this topic. For years they were too quiet. It is not a fast process, but there are efforts to include all judges. That is why his advice is: Start immediately: Without a constitutional amendment, without changing the current structures! The judges' participation in their own working conditions does not require a basis in written law (van Lierop).

- From the perspective of the Norwegian judge, independence starts in your head. 10 years ago, when Norway completed its judicial reforms and the court administration was transferred from the Ministry of Justice to an independent organ, a strong minority of judges rejected this solution because they were of the opinion that you shouldn't do away with a system that had worked well for decades. They were afraid it would weaken the position of the courts in the budget negotiations and thus negatively influence the distribution of funds to the courts. They also shied away from the responsibility for an effective court management, which they then had to take on. But the decision was made by the majority of the judges and passed by parliament. In those 10 years a lot has been discussed about judicial independence and what is to be understood with that term, also with lawyers and professors. Today, you would be hard-pressed to find a judge who is of the opinion that the reform was a mistake. He therefore agrees with Mr. Van Lierop that: It all depends on starting the discussionimmediately! The Norwegian experience showed that it is possible to transform the judges' attitudes within 10 years (Engstad).

- The Dutch judge added that international meetings are often concluded with a declaration. For this meeting, the title - the Berlin Declaration, so to speak - could be: Throw off your chains! Emancipate yourselves! He says that as a joke, but they are all convinced that if you tackle a situation, it will change (van Lierop). 
- The German CCJE representative sees it as a hopeful sign that in recent years there have been steps taken towards more self-administration. To name just one of them, he reported that the majority of second-instance judges in his court district have formed a kind of quality circle. There, for example, they have interviewed judges and then compared results. He is convinced that you can learn something from these results and is trying to persuade his colleagues to repeat these interviews in order to see how the results have changed. With the questions, they try to ask about the so-called hard and soft skills. In this way, they also try to determine the satisfaction of employees, for example. He says this to show that there are certainly self-initiated projects. This quality circle was started only from the judges' organization. In the court district Cologne the district courts have now been talked into starting such a comparative circle. In doing so, however, you need to remember that the goal is not to get a ranking of the courts but only to learn from the others how to improve (Riedel).

\section{Budget authority for the third power}

- The representative of the German Judges Association gave reasons for why, in her opinion, more autonomy should be demanded for the courts: Every judge should feel responsible for the judiciary. That is connected to the professional ethical standard of how you should best lead the proceedings, for example, or that you should make yourself aware of your task. If you can do this, then you are doing your job well and don't see it as just a job. This change of attitude is promoted by self-administration. This also means that administrative tasks are not just passed on to the administration but that you do them yourself. The area of budget shows that this approach can work well. In many Länder, the courts can administrate and distribute part of the budget themselves. However, this applies only to a small sector. Personnel costs and costs for building conditions and other key expenditures are still controlled by the ministry. Only parts of the non-personnel costs are subject to the budgeting. In this area, however, the management of funds is carried out very responsibly by the courts. In the cases she's familiar with, every year some money remains. The independent management of funds guarantees that the money is used where it is needed. In Germany, as well, one sees that particularly the budget can have effects on independence: with the pressure to save and budget cuts, the pressure to complete cases and the workload of each individual judge increases immensely. In Hamburg, the lawyers have gotten together with the judges in order to call for more resources for the judiciary from the first mayor. The deficits are therefore already tangible for third parties. By the way, this is something that is not known in the general public and therefore also can't contribute to the trust or mistrust in the judiciary (Kreth).

- For the Austrian judge, as well, the aspects of budget authority and independence are closely connected. A tendency can be seen that across issue areas, increasingly more is budgeted and managed together. Certain projects, e.g. IT use, were imposed on the judiciary for rationalizing reasons which often leads to priorities being set by over- 
arching state interests that aren't in line with the local needs, and this leads to resentment. This then leads to a distancing from the workplace. From this realization, he believes that it logically follows that one must include the judges in the conceptualization, in setting priorities, and in budget distribution. The phenomenon of lawyers starting to work together with judges to ask for more funding for the judiciary can also be seen in Austria (Reissner).

- The Dutch judge reports that his country has found its own way to finance the courts. Each type of proceeding or each procedural step is assigned a certain value. This value or price for the judicial service is derived from the collective experiences of how many resources a judge or a chamber invests on it on average. The courts receive their budget according to the prices for a procedure depending on the number of proceedings required. It is claimed that these values were reached objectively and are based on experience and statistics. The Highest Judges' Council then goes to the parliament with the prognosis of the number of proceedings that will be concluded in the following fiscal year. The courts are then assigned the corresponding budget - transferred by the judges' council (van Lierop).

- According to the perspective of the judicial representative from Switzerland, the competency of the third power to create its own budget and also bring it to parliament has far-reaching consequences. In times of financial problems, one is confronted with the necessity to make budget cuts. In the individual cantons the call is becoming louder that the judiciary should make cuts as well, with the buildings, maybe by changing the procedural order and using more individual judges instead of councils. That last point was suggested recently in one canton to the parliament by the government with the consequence that the number of judges was reduced. The judges then protested because this was seen as an attack on the judicial self-administration. They stuck with their budget, which was then accepted by parliament. This positive ending was in opposition to the earlier experiences that had been had when the Ministry of Justice was still responsible for presenting the budget. Then, cuts were always made, and the judiciary was one of the areas in which cuts were made first, e.g. for structural developments - in contrast to the general administration, in which investments were continually made. For him, budget authority is an important factor in order to further develop court self-administration and promote the independence of the judges and courts. In addition, with the participation of the individual judges, their motivation was increased because they demanded that they be able to take on additional and different fields of work. The negotiations with parliament are led by the presidents of the highest courts of the cantons, but they are sometimes represented by their vicepresidents (Gass).

- The Austrian judge explained that from the outside there are always doubts that the judges could work out their budget themselves. He doesn't understand where this view comes from. The objection is just a defensive reaction and not factually accurate. If you are not able to identify cost-increasing factors, then that is incompetence, regardless of whether this is from the ministry or a judges' council. For him, beyond the 
motivation and independence aspects, there is another advantage of budget authority - that this allows for a distribution of costs that reflects actual needs, or that funds can be saved where they will be least needed, e.g. by postponing large projects (Reissner).

- As a summary, the judge from Great Britain stated that the judges do not have any competency to request their budget, but they are included in the process and are also represented in the council that carries out the final distribution of the approved budget. Currently, however, there are no efforts among judges to achieve greater participation (Sir Aikens).

- The Croatian judge explained that in Croatia, the judiciary has no financial autonomy. The budgetary competency is centrally held by the Ministry of Justice. There the budget is prepared before it is brought before parliament by the government as part of the total budget so parliament can approve it. The constitutional court has an advisory role in this process. Since its advice is never followed, however, in recent years it has declined to participate. Autonomy is also always connected with responsibility for results. For him, financial autonomy is therefore a worthy goal if it could improve the functionality of the courts, and one factor for this is the possibility to react faster to deficits (Sessa).

- For the representatives of the New Judges Association, this raises the question of what the judiciary is allowed to cost. One is always frivolously ready to agree to general cuts. But he believes this is a mistaken approach. Particularly in economically difficult times, the judiciary usually has more to do. This does not mean that the budget needs to be increased. But you should also ask the basic question of what the judiciary in Germany is allowed to cost on average. In the individual Länder the judicial budget is usually only two to three percent of the total budget. Even these numbers are too high since external costs are included. In the end it is less than 1.5 percent of the state budget that is spent on the judiciary. That is so little that you have to ask how much justice is worth in a democratic, rule-of-law state in which the citizens can trust and that also must function in difficult times (Stötzel).

- The Norwegian judge reported that in his country the courts are also somewhat selffinanced. Revenues are more than expenses, but the courts don't get to keep the money - it is assigned to the general budget. Of course the question of who negotiates the budget with parliament is important. In Norway, as well, there was a great fear when the court organization was changed that the courts would not be sufficiently qualified for this. Today, in principle the Ministry of Justice prepares the budget and first enters into negotiations with the Ministry of Finance before the budget is brought to parliament. Since parliament only carries out a few changes, in reality it is the government that makes the budget. In the first years after the change, the budget was able to be increased. In recent years there have been fewer efforts made by the government to provide sufficient funding for the courts. That should also be seen as a political decision. One is also competing, for example, with the police, which is more difficult 
in times where the security needs of the people are changing. In recent years the budget has therefore been reduced. This is not linked to the design of the system, however: It is political priority-setting, and politics are not always oriented on rational measures. In his opinion, politicians are not always sufficiently aware of the importance of the independence and efficiency of the courts - despite numerous publications on the link between independent and efficient courts and an increase in social well-being. For him it is therefore still difficult to understand why politicians are cutting resources for the court (Egnstad).

- The Romanian judge reports that in her country, a mixed system was decided upon. The Ministry of Justice sets the budget for the first and second instances, while the higher courts have the right to request their own budget. However, the judges are also included in the creation of the budget for the lower instances. Suggestions can be submitted to the Ministry of Justice, for example. Small successes can also be achieved. The highest cassation court and the constitutional court, for example, were able to obtain additional funds for the judiciary in negotiations with the president. In the law you can also find a passage declaring that the president of the highest cassation court may act as the sole representative of the judiciary. There were attempts to transfer this to budgetary rights, but it was not successful (Popa).

- The Austrian judge added that the minister is also a member of the government, and it therefore becomes normal that exchanges among issue areas are made when creating the overall budget that are by their very nature not always in the pure interest of the judiciary. In his opinion, the negotiation of the budget by an independent organ would on the one hand make clear to external observers the autonomy of the judiciary and on the other hand would strengthen the self-confidence internally. The CCJE has already written two positions on the topic. It was recommended that the judges have key co-determination rights in the creation and management of the budget. In addition, it was pointed out that the judiciary needs sufficient financial resources (Reissner).

\section{Safety Mechanisms for Judicial Autonomy by Improving Public Perceptions}

\section{Country-specific summaries}

The representatives from each of the four countries almost unanimously agreed that media reports about proceedings and individual judges can be used to influence the contents of a decision. It is therefore seen as necessary to institute protective measures for the independence and autonomy of the courts. Despite this insight, the relationship of the judiciary with the public and media is dealt with as an afterthought. 


\section{Protection of autonomy with self-administrative organs}

From the discussions, it was clear that a self-administrative organ is in principle suited to improve the picture of the judiciary in the public eye. Unified, effective public relations measures could be introduced, and the judiciary could be given a respectable face.

The extra representation and communication with the media requires professional training of those involved. Judges are usually overwhelmed with this task. They must decide cases based on law, and from their unbiased role and their position, they are hardly capable of explaining their decisions to a broader public.

\section{Country-specific approaches}

The Dutch Judicial Council reports of the success of efforts to achieve judicial transparency, the acceptance of the inclusion of all court branches into public relations work, and of successfully informing the public of legal matters.

In Italy, the Highest Court Council (CSM) even takes on the protection and support of judges who were criticized publicly. The consequence is often the accusation of the politicization of the justice system, and even foreign media reports of the "Italian judiciary as a political actor."

In Poland, the National Judicial Council does not place much importance on the extra representation of the judiciary. It does, however, attempt to be present in electronic media and has set up online portals in order to improve the transparency of legal practice.

In Switzerland, the self-administration is rather seen as a hindrance for the unified representation of the justice system. At the same time, even here there are professional approaches in the area of public relations which are different from court to court and canton to canton. In general, the question is raised as to whether a self-administrative organ can represent and defend the judiciary externally and yet still be connected to the structural organization of self-administration. The more direct the autonomy of the individual judges is exercised, the less a self-administrative organ can "speak for the courts."

\section{Comments from the CCJE debate}

In summary, one can say that across Europe there is a broad consensus that independent judges' councils can significantly contribute to the improvement of the judiciary's communication with the citizens and media. Various paths have been laid out: 


\section{Independent judges' councils shape and improve the judiciary's communication} abilities

- The Slovenian judge assumes that the opinion of the judiciary is substantially influenced by its representation in the media. Since trust in the judiciary is not very high in Slovenia, a study on the topic was commissioned that showed interesting results. The media reports about the judiciary have increased by more than 600 percent in recent years. In addition, the satisfaction of those who had actually come in contact with the judiciary was much higher than among the general population. Because the external effects of the judiciary is an important factor, one should ask who should and may represent the judiciary and in which cases statements should be made. Recently in Slovenia there have been many politically motivated attacks by the media on courts and individual judges. Now the judiciary is asking whether it should react. The majority is of the opinion that they should, even solely because they don't want the accusations to gain the ring of truth by constant repetitions. These cases have shown, though, that who speaks for the judiciary and when needs to be more clearly regulated (Betetto).

- The Dutch judge said that he-although he is very critical of the function of the Highest Judges' Council in the Netherlands on many points - admires its work in the area of communication with the public. The council is very actively involved in creating a positive public image. There are open door days (and even nights) at the courts, public events, moot courts, children's days, and numerous press releases. They want to convey transparency. He is very open to this part of the work. However, the judiciary is not a company that needs to try to sell its product. In general - and this is also culturally dependent - the public has a great deal of trust in the judiciary in the Netherlands. The CCJE has also published a position on the relationship between the judiciary and media/population and emphasized the role of pro-active communication in which a highest judges' council can play an important role (van Lierop).

- The Spanish judge reported that in his country a separate department has been set up for the judiciary's communication with the media at the level of the individual courts. The judges are also free to express their opinions - usually on the topic of judicial independents - to the public, often mediated by the judges' associations. Usually the judges' associations refrained from commenting on current court proceedings, however (Sàenz).

\section{The creation of judicial transparency is the task of independent judges' councils}

- The judge from Great Britain stated how they try to communicate with the population in his country. For example, it is normal that there is an open day for the judiciary. This exists across the country. Judges go to schools and tell students about the work in court. Children visit the courts and take part in mock trials. In addition, all meetings are public so that school classes often visit them. Judges are also encouraged to teach at universities and keep in contact with students. For students there is also the possi- 
bility to complete a kind of internship for around one week at the appellate courts. When judges are attacked in the media for their decisions, a so-called "Judicial Communication Office" is responsible and protects the judges (Sir Aikens).

- For the Norwegian judge, transparency is an important element of strengthening public trust in the courts. To come back to the CCJE position paper: One of the recommendations was that the courts should be more pro-active in approaching the media. An advantage of setting up an independent judicial administration in Norway was that this area was greatly professionalized; an independent organ can take on this task better than the Ministry of Justice, which is not part of the third power. The Norwegian judges' association has dealt with this topic more extensively since 2005/2006 and pointed out to the judges the necessity of transparency in dealing with the media and the public. As a result, a working group made up of five to six judges was established who received special training in dealing with the media and are now available on a rotating basis for questions from the media - whether about specific proceedings or on the court organization in general. This has contributed to an improvement in the communication with the media and thus public opinion of the judiciary. For this aspect, as well, the establishment of a highest judges' council was a good solution (Engstad).

\section{Creation of regulations for public communication is the task of judges' councils}

- The Romanian judge reported that the Highest Judges' Council has published a set of regulations that created guidelines for when judges may or should comment on proceedings in the media. The Highest Judges' Council reacts to attacks from the media against individual judges and has the possibility to bring up issues to the national media council and defend the judges (Popa).

- For the Croatian judge, the greater danger lies in politicians using the media to lay out demands for the judiciary. In these cases, the courts must react quickly, particularly because the public is not really sensitized to the nuances of independency and because the impression could otherwise be created that the courts have to follow such demands. On this topic there is also an extensive set of decisions by the ECtHR that sets strict limits for politicians (Sessa).

- The Dutch judge told about a slogan from the Dutch Judges' Council that is printed on many marketing materials: "The judiciary makes it possible to live together." At first it sounds like a joke, but it's not. Open communication with the public is not only important for the self-representation of the judiciary but also in order to show that the judiciary is essential for the maintenance of democracy, the rule of law, and human rights. In brief: the principles of the ECHR (van Lierop). 


\section{E. Safety Mechanisms for Independent State Prosecutor's Offices}

\section{Country-specific summaries}

\section{The European principle of separation state prosecutor's office from the courts}

With the exception of Italy, in the three countries Poland, the Netherlands, and Switzerland, the state prosecutor's office is clearly separated from the third power. The majority of the questioned representatives were in favor of the separation in the future, as well:

In the Netherlands, the separation was introduced by the modernization processes at the turn of the millennium. The state prosecutor's office is responsible to the Ministry of Justice, and the Ministry has the authority to give directives. Because the state prosecutor's office is not only obligated to the goal of truth-finding, but also takes on criminalpolitical tasks such as fighting crime, there it should not participate in the independence of the third power.

In Poland, as well, one shares this view in principle. The state prosecutor's office is seen there as an organ of justice, but it was not made into a constitutional organ. The call for independence is not followed. The state prosecutor's office is hierarchically structured and, due to the contradictory function, is not an element of the independent third power.

In Switzerland, only recently was the state prosecutor's office restructured in the cantons as an investigative and prosecuting body. It is responsible to the Ministry of Justice, but it does not receive directives from the Ministry. A newly formed state prosecutors' council has taken on the function of supervision.

Even in Italy, where the state prosecutor's office has historically belonged to the independent third power, there is a trend towards building hierarchies and dismantling the common structures with the courts. Although this is criticized by the judges, there have been repeated efforts to exercise political influence on the work of the state prosecutor's office.

\section{European trend: independent criminal prosecution}

In three of the four countries, the state prosecutor's office is not an element of the third power. At the same time, one could call the independence of criminal prosecution in the state prosecutor's office a common European desire bound to different forms of implementation, for example with (The Netherlands, Poland) and without (Suisse) the right for the ministries of justice to give directives. 
II. Currently, the CCJE debate can be summarized as follows:

There is no judicial independence without autonomy for the state prosecutors. If the state prosecutors have leeway to stop proceedings in a way that is uncontrollable and able to be influenced by politics, then the judiciary can only decide on what is brought to trial. That is why the state prosecutors must enjoy the same autonomy rights as the judges. How that is to be organized would be another question. One could understand the state prosecutors as part of the third power or as an independent organ with comparable rules as those for judges.

\section{F. Conclusion}

\section{Ten Safety Mechanisms for the Autonomy of the Third Power in Europe}

1. Autonomy of the third power in a democratic, rule-of-law state is a necessary conclusion from the central constitutional principle of the separation of powers.

2. Dual control systems made of judicative and executive prove to be disruptive for the autonomy of the third power.

3. The third power's budgetary rights follow from its autonomy.

4. Direct election of judges by the parliament or independent election committees strengthen the legitimacy and thus the autonomy of the third power.

5. Judges' elections require a high degree of transparency and thereby promote the legitimacy and autonomy of the third power.

6. The third power's self-administration is a condition for the development of autonomy.

7. Self-administrative units with majority decisions ideally require a manageable size; self-administrative organs require democratic links with the majority of the judges.

8. Mechanisms of executive personnel control reduce the autonomy as well as the efficiency and quality of adjudication.

9. Administrative experience and administrative practice by judges promote the efficiency and quality of their work.

10. State prosecutors should be better protected from external influences. This demand is developing across Europe. 